\title{
Enhancement of heat transfer using twisted tape insert in a plain tube
}

\author{
Taha Tuna GÖKSU ${ }^{1}$, İbrahim Halil YILMAZ ${ }^{* 2}$ \\ ${ }^{I}$ Department of Mechanical Engineering, Adiyaman University, Adiyaman, Turkey \\ ${ }^{2}$ Department of Automotive Engineering, Adana Science and Technology University, Adana, Turkey
}

\begin{abstract}
The use of insert within a tube is one of the techniques enhancing the convective heat transfer coefficient at the expense of hydraulic loss penalty. This mutual effect which is a strong function of insert geometry and flow conditions is to be analyzed in detail to improve the overall system performance. This study presents a numerical investigation for analyzing the thermo-hydraulic characteristics of twisted tape insert in a plain tube (with a 13mm-diameter and 1200-mm-long) which is widely used in refrigeration applications where the compactness of the heating/cooling component is significant. The effect of twist ratio on the thermo-hydraulic performance was conducted for the Reynolds number range of 5,025-14,871 where most of refrigeration applications are operated in. The verification of the simulation results was compared to Dittus-Boelter empirical equation (for the plain tube case) and good agreement was obtained. Results indicate that the variation of the twist ratio between 6-9 increases the friction factor and Nusselt number $197-245 \%, 180-220 \%, 163-189 \%$ and $156-179 \%$, and $32-54 \%, 28-46 \%$, $28-33 \%$ and $28-33 \%$ relative to the plain tube case, respectively for the specified operating conditions. The performance evaluation criteria, which are measure of enhancing heat transfer against hydrodynamic forces, changed between $0.90-1.02,0.89-1.00,0.91-0.96$ and $0.92-0.96$ based on the twist ratio rise. The maximum enhancement in the performance evaluation criteria was obtained at the lowest Reynolds number and twist ratio. The performance evaluation criteria lower with increasing Reynolds number but can be increased by increasing the twist ratio.
\end{abstract}

Keywords: Heat transfer enhancement, Twisted tape, Twist ratio, Performance evaluation criteria.

\section{Düz tüp içerisinde burulmuş şerit kullanarak ısı geçişinin iyileştirilmesi}

\section{$\ddot{O} \mathbf{z}$}

Tüp içerisinde ilave parça kullanımı, taşınım ısı geçişi katsayısını artırmak için hidrolik kayıp zafiyeti pahasına kullanılan tekniklerden biridir. İlave parça geometrisinin ve akış koşullarının güçlü bir işlevi olan bu müşterek etki, toplam sistem performansını iyileştirmek için ayrıntılı şekilde analiz edilmelidir. Bu çalışma, 1sıttma/soğutma donanım kompaktlığının önemli olduğu soğutma uygulamalarında sıkça kullanılan burulmuş şerit ilavesi yapılmış düz bir tüpün (13 mm çaplı ve $1200 \mathrm{~mm}$ uzunluğunda) termo-hidrolik karakter analizinin sayısal olarak incelenmesini sunmaktadır. Burma oranının termo-hidrolik performans üzerindeki etkisi, soğutma uygulamalarının ekseriyetinin çalıştı̆ı $5.025-14.871$ Reynolds sayısı aralı̆̆ında incelenmiştir. Benzetim sonuçlarının doğrulanması deneye dayalı Dittus-Boelter denklemi ile kıyaslanmış (düz tüp için) ve iyi bir uyum elde edilmiştir. Sonuçlar, burma oranının 6-9 arasındaki değişimi, belirtilen çalışma koşullarında düz tüpe kıyasla sürtünme faktörünü ve Nusselt sayısını sirasıyla \%197-245, \%180-220, \%163-189 ve \%156-179 ve \%32-54, $\% 28-46, \% 28-33$ ve \%28-33 arttırdığını göstermiş̧ir. Hidrodinamik kuvvetlere karşı 1sı geçiş miktarının artırılmasının bir ölçütü olan performans değerlendirme kriteri, burma oranı artışına bağlı olarak 0.90-1.02, $0.89-1.00,0.91-0.96$ ve $0.92-0.96$ arasında değişmiştir. Performans değerlendirme kriterindeki maksimum artış, en düşük Reynolds sayısı ve burma oranında elde edilmiştir. Performans değerlendirme kriteri Reynolds sayısının artışıyla azalmakta ancak burma oranının arttırılmasıyla yükseltilebilmektedir.

Anahtar kelimeler: Isı geçişi iyileştirme, Burulmuş şerit, Burma oranı, Performans değerlendirme kriteri.

\footnotetext{
*Sorumlu yazar: iyilmaz@adanabtu.edu.tr

Geliş Tarihi: 21.09.2018, Kabul Tarihi: 05.02.2019
} 


\section{Introduction}

Heat transfer enhancement is usually needed to increase both the thermal performance of a specified system and its compactness. Passive heat transfer enhancement which is one of the enhancement methods does not require any prime mover. Hence, it is particularly used in simple systems such as pipe flow where the heat transfer enhancement is managed for a cost effective solution. However, enhancing the heat transfer is performed against hydrodynamic forces which are unavoidable due to shear stresses and pressure [1]. The use of insert, treated and extended surfaces or vortex generator is the typical scheme of this method [2]. The insert is widely used among these schemes. Wire coil (WC) or twisted tape (TT) is the favorable insert geometries since they improve the overall heat transfer better with respect to their counterparts [3].

Enhancing heat transfer by inserts has been studied by numerous researchers. However, we limited the literature review only to the studies being related to TT since there are various geometries applied to it for heat transfer enhancement. These studies were performed either numerically or experimental or both of them. The thermo-hydraulic characteristics of TT engaged tubes were investigated based on different insert properties to analyze the effects of such as twist ratio $[4,5]$, clockwise-counterclockwise arrangement [6, 7], cross hollow TT [8], spirally grooved tube [9], spirally grooved tube with overlapped large/small twin TTs [10], two-phase flow [11], V-cut TT [12], coupling of TT with WC [13, 14], twin-counter/co-swirl tape [15], double counter TT [16], triple TT [17], and quadruple TT [18].

The literature studies constantly indicate that all the configurations being applied have increased the heat transfer enhancement or Nusselt number $(\mathrm{Nu})$ at the expense of pressure drop or Darcy's friction factor $(f)$ rise. Besides, the heat transfer enhancement in laminar regime is higher relative to turbulent regime due to stream-wise flow structure. Increasing the flow rate of fluid in turbulent regime has a significant effect on the heat transfer enhancement. On the other hand, reducing the twist ratio of TT increases both Nusselt number and friction factor however both these factors affect the overall heat transfer performance which is a function of Nusselt number and friction factor, named PEC (performance evaluation criteria). PEC is a measure of ability to augment the heat transfer in a tube by modifying the geometry or inserting turbulence promoters which result in better thermo-hydraulic properties with respect to the plain tube. By definition, increasing PEC over unity means that the heat transfer is enhanced thermodynamically even higher pressure drop exists. This may not always be the case in the systems where heat rejection/gain is a must or improves the overall performance as a consequence.

Cross-flow heat exchangers are commonly used in gas heating or cooling including such refrigeration systems $[19,20]$. A tube bundle carries a heating or cooling fluid (either gas or liquid), normally perpendicular to a gas flow which passes over the tubes and allows heat to be transferred between the fluids. The aim of this study is to fill the gap in the literature by numerically investigating the parametric effect of the twist ratio $(\mathrm{TR}=\mathrm{P} / \mathrm{D})$ of TT engaged in a plain tube which is widely used in refrigeration applications where the compactness of heating/cooling elements is considerable. A numerical model has been developed in Ansys Fluent for the tube geometry. For $2 \mathrm{~mm}$ thickness TT, the TR from 6 to 9 has been studied for the Reynolds number (Re) range of 5,025-14,871 using air as a working fluid.

\section{Numerical Approach}

\subsection{Geometry}

Figure 1 shows the geometry of the insert and its coupling with a plain tube. There are various specifications in piping work of the heating/cooling systems. The pipe diameter and the length of pipe are determined based on the heat transfer area needed. In this study, a standard tube with $13 \mathrm{~mm}(1 / 2$ inch) in diameter and $1200 \mathrm{~mm}$ in length was modeled in Ansys Workbench. Thickness of the TT is equal to $2 \mathrm{~mm}$, and its TR ranges from 6 to 9 . 


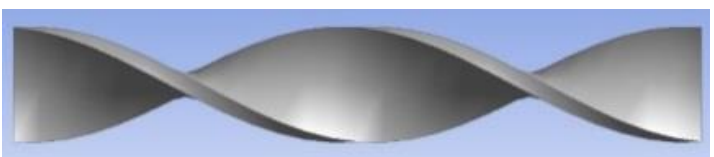

(a)

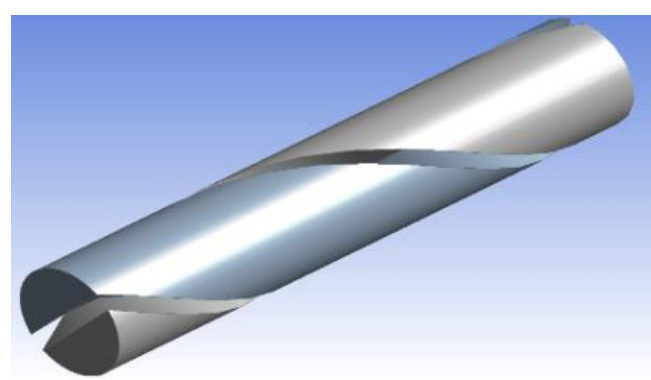

(b)

Figure 1. TT engaged in a tube. (a) twist geometry, (b) TT coupled with tube

\subsection{Mesh}

Two mesh studies were conducted respectively. The first one was employed for the plain tube. The number of mesh elements with 798,488, 2,048,357, and 4,303,415 was applied for this geometry. Nusselt number and friction factor deviation for 2,048,357 and 4,303,415 mesh studies were obtained lower than $1 \%$. For this reason, 2,048,357-mesh element was used for the plain tube case. The second mesh study was applied to the plain tube with TT insert. 2,726,000, 2,852,000, 2,790,000, and 2,856,000 mesh elements were used for the case of varying TRs of $6,7,8$ and 9, respectively. Figure 2 illustrates the inlet meshes of the plain tube and the plain tube with TT insert, and the wall mesh of the TT inserted plain tube, respectively.

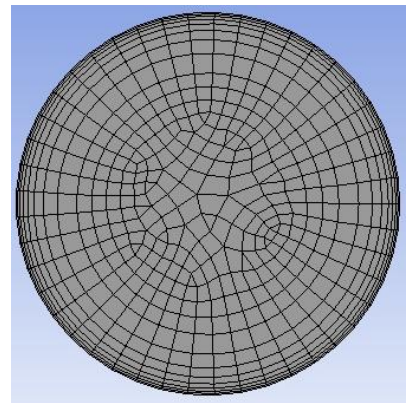

(a)

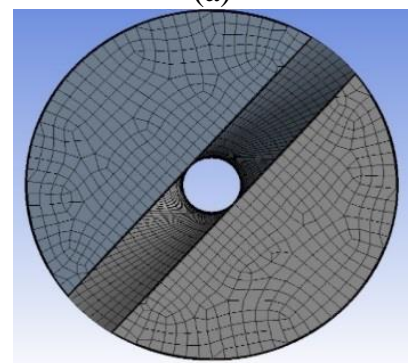

(b)

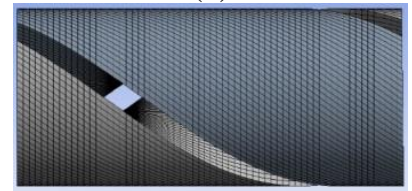

(c)

Figure 2. Mesh structures for the cases of (a) plain tube, (b) plain tube with TT, (c) wall mesh of TT 


\subsection{Boundary condition}

The flow direction is specified as normal to the tube cross-section. A uniform heat flux was applied on the tube wall as $1000 \mathrm{~W} / \mathrm{m}^{2}$ for each set of numerical analysis. Air was selected to be the working fluid whose inlet temperature was taken as $298.15 \mathrm{~K}$. The flow regime is considered to be turbulent where Reynolds number varies from 5,025 to 14,871 . This range corresponds to the mean velocity of $4-15 \mathrm{~m} / \mathrm{s}$ where most of refrigeration applications are operated in.

\subsection{Numerical solution}

The commercial computational fluid dynamics solver Ansys Fluent was used for numerical analyses. Semi-implicit pressure linked equation (SIMPLE) algorithm for pressure-velocity coupling, spatial discretization for gradient (least square cell based), pressure (second order), turbulent kinetic energy and dissipation rate (first order upwind), momentum and energy (second order upwind) and standard k- $\varepsilon$ turbulence model with the option of enhanced wall treatment were employed for engaging the governing equations together with the boundary conditions over the computational domain. The y+ value about 1 was ensured for all analyses to obtain the high resolution of gradients in the near wall regions. The solution convergence criterion was satisfied as the scaled residuals less than $10^{-6}$ for energy, and $10^{-4}$ for momentum, continuity, $\mathrm{k}$ and $\varepsilon$.

\subsection{Calculation of thermo-hydraulic fluid properties}

The following equations were used for the calculation of numerical results:

Reynolds number (Re):

$$
\operatorname{Re}=\frac{\rho U_{m} D_{h}}{\mu}
$$

Darcy's friction factor $(f)$ :

$$
f=\frac{2 \Delta P D_{h}}{\rho U_{m}^{2} L}
$$

Blasius equation for plain tube friction under turbulent flow:

$$
f=\frac{0.316}{\operatorname{Re}^{0.25}}
$$

Nusselt number $(\mathrm{Nu})$ :

$$
\mathrm{Nu}=\frac{h D_{h}}{k}
$$

Dittus-Boelter equation for plain tube:

$$
\mathrm{Nu}=0.023 \operatorname{Re}^{0.8} \operatorname{Pr}^{0.4}
$$

Heat transfer rate:

$$
\dot{Q}=\dot{q}_{s} A_{s}=\dot{m} c_{p}\left(T_{o}-T_{i}\right)
$$


Convection heat transfer coefficient:

$$
h=\frac{\dot{Q}}{A_{s}\left(T_{w}-T_{b}\right)}
$$

Outlet temperature for working fluid:

$$
T_{o}=T_{i}+\frac{h A_{s}\left(T_{w}-T_{b}\right)}{\dot{m} c_{p}}
$$

Performance evaluation criteria (PEC):

$$
\mathrm{PEC}=\frac{N u_{a}}{N u_{o}}\left(\frac{f_{a}}{f_{o}}\right)^{1 / 3}
$$

As mentioned before, PEC is a measure of how effectively the heat transfer is enhanced at the expense of hydrodynamics forces. Its value is to be greater than unity for enhanced heat transfer. Otherwise, the insert does not benefit to convection transfer, and the tube thermally behaves like a plain tube. In Eq. (9), $\mathrm{Nu}_{a}$ and $\mathrm{Nu}_{\mathrm{o}}$ describe the Nusselt number for the TT inserted tube and plain tube, respectively. Similarly, $f_{a}$ and $f_{\mathrm{o}}$ describe the friction factor for the TT inserted tube and plain tube, respectively.

\subsection{Model validation}

Similar boundary conditions mentioned in Section 2.3 was employed for the model validation of the plain tube. Figure 3 and 4 show the comparisons of the numerical results with the experimental results for friction and Nusselt number. As clearly seen from the figures, the results of Nusselt number and Darcy's friction factor are in good accordance for the Reynolds number range of 3,880-18,432. While the deviation of the numerical results for Nusselt number varies between $5.6-11.0 \%$, it is between $2.1-4.1 \%$ for the friction factor case.

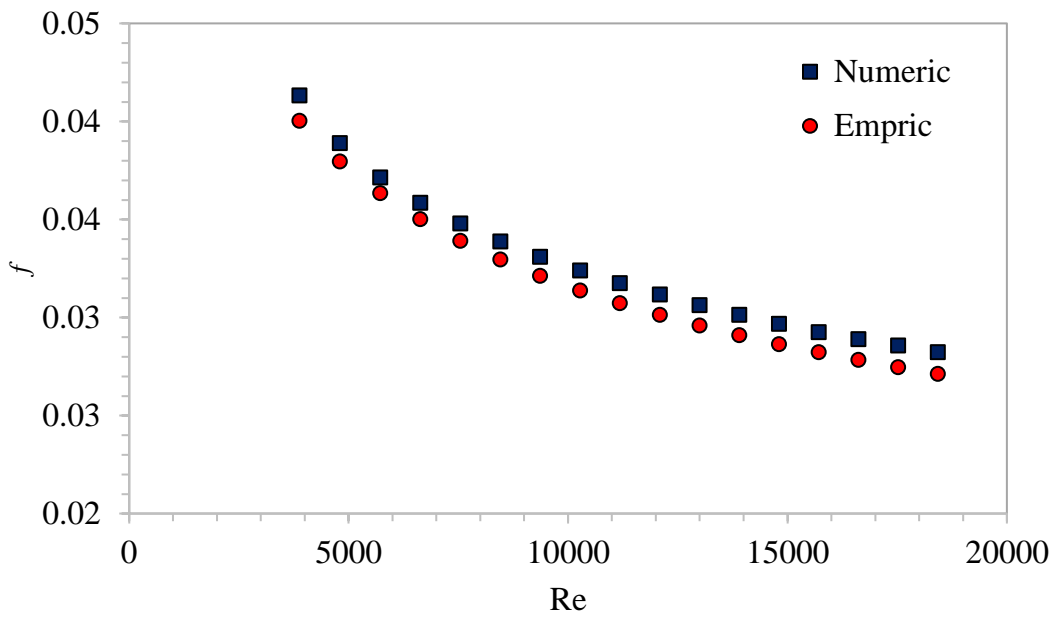

Figure 3. Comparison results for friction factor. 


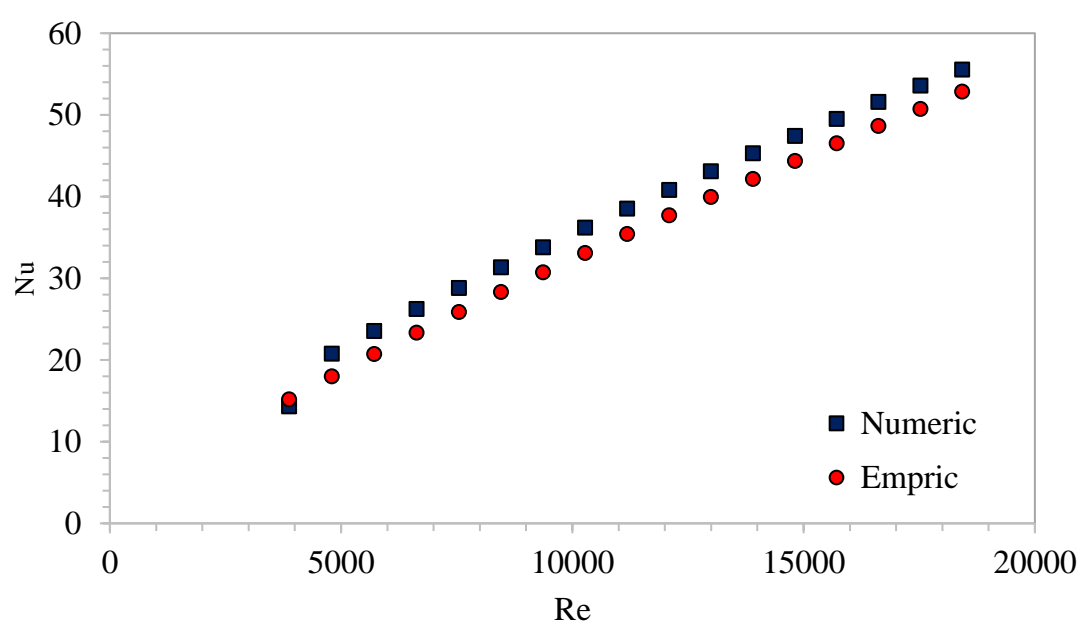

Figure 4. Comparison results for Nusselt number.

\section{Results and Discussion}

In this study, the effect of TR on the hydrodynamic properties of the insert engaged tube flow was investigated. Figure 5 and 6 illustrate the variations of friction factor and Nusselt number as a function of Reynolds number for varying TRs. It is seen from Figs. 5 and 6, Nusselt number and friction increase with reducing TR by $28-54 \%$ and $156-245 \%$, respectively within the operating domain. While the highest Nusselt number is obtained for the TR of 6 at increased Reynolds number, the highest friction factor is obtained for the same TR but at the lowest Reynolds number. Nusselt number changes almost linearly with increasing Reynolds number as clearly seen. The effect of TR on Nusselt number is almost the same at higher Reynolds number however it results in $\sim 35 \%$ enhanced heat transfer relative to the plain tube case. On the other hand, the friction factor is strongly affected by TR. As expected, lowering the TR has negative effect on friction factor. It almost levels off at increasing Reynolds number and reaches the normalized level of $\sim 180 \%$ as compared to the plain tube case. It is concluded that increasing the TR yields similar Nusselt number results, the friction factor is rather increased. This would make negative effect on PEC.

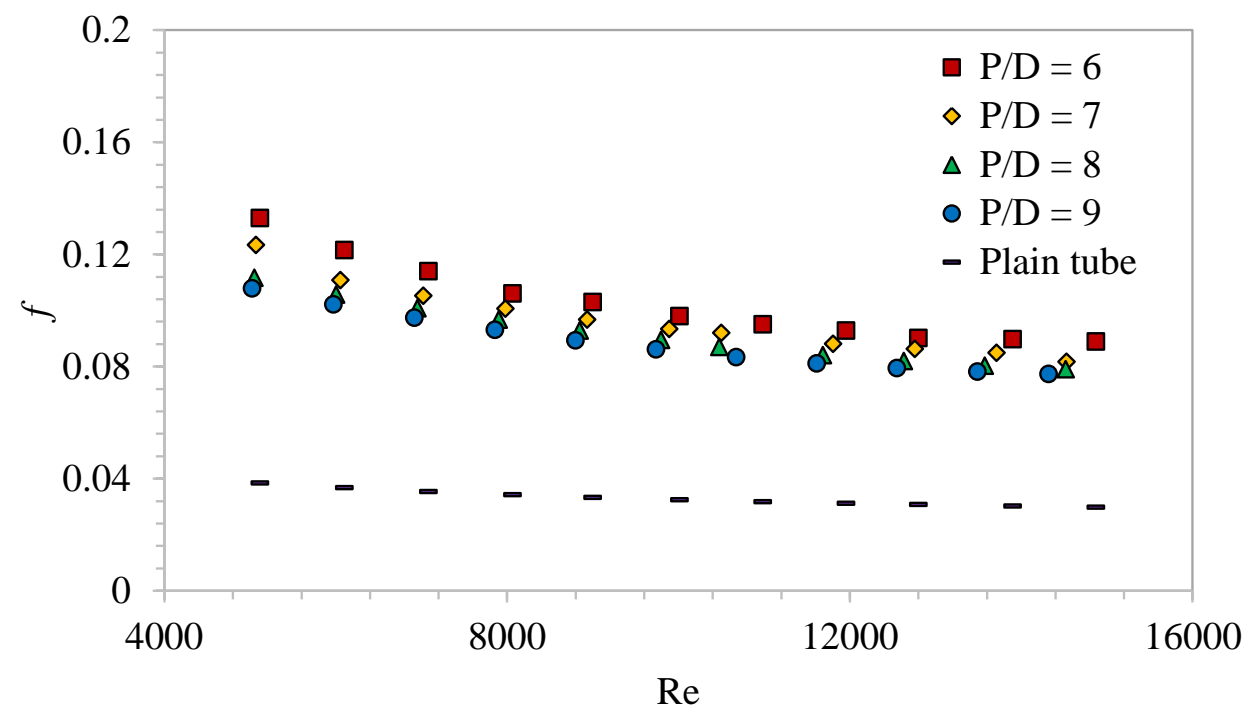

Figure 5. Variation of friction factor with TR based on Reynolds number 


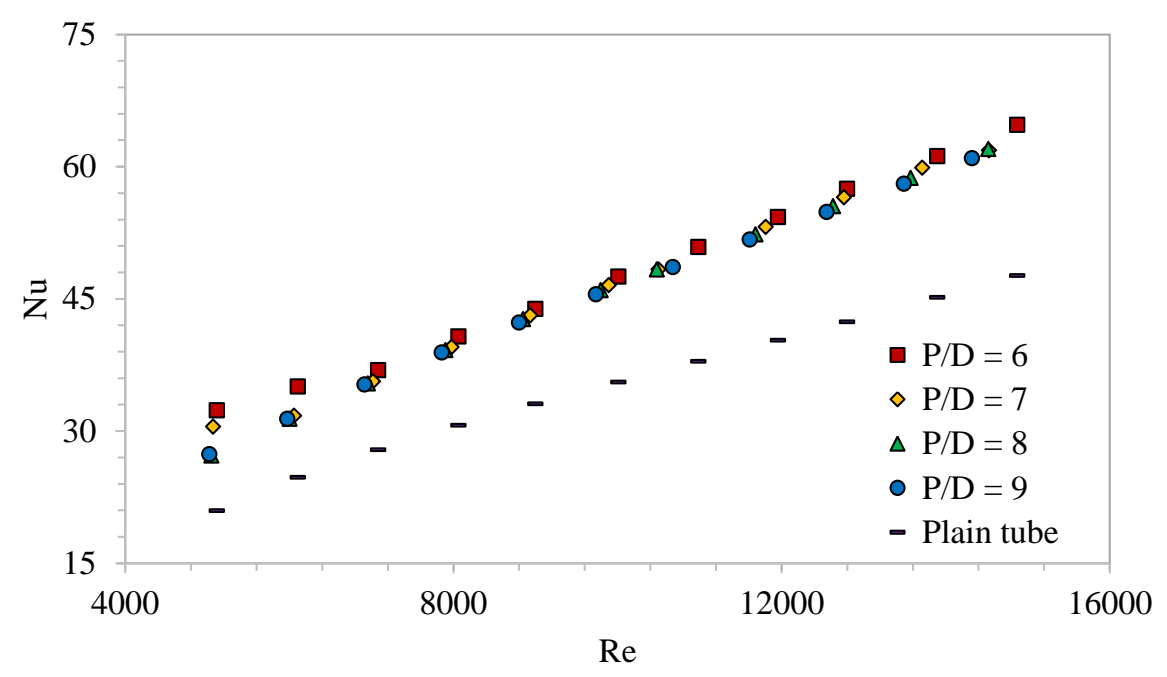

Figure 6. Variation of Nusselt number with TR based on Reynolds number

Figure 7 indicates how PEC varies with increasing TR and Reynolds number. PEC varies between $0.9-1.02,0.89-1,0.91-0.96$, and $0.92-0.96$, respectively as the TR increases from 6 to 9 . Although the friction factor increases with lowering TR, highest PEC is obtained at the lowest TR. As clearly seen, PEC is higher than unity as Reynolds number is equal to 5,114. This shows that the use of twisted tape is more reasonable at lower Reynolds numbers such as in air conditioning applications or else where the heat transfer enhancement is much significant and essential than the pressure loss.

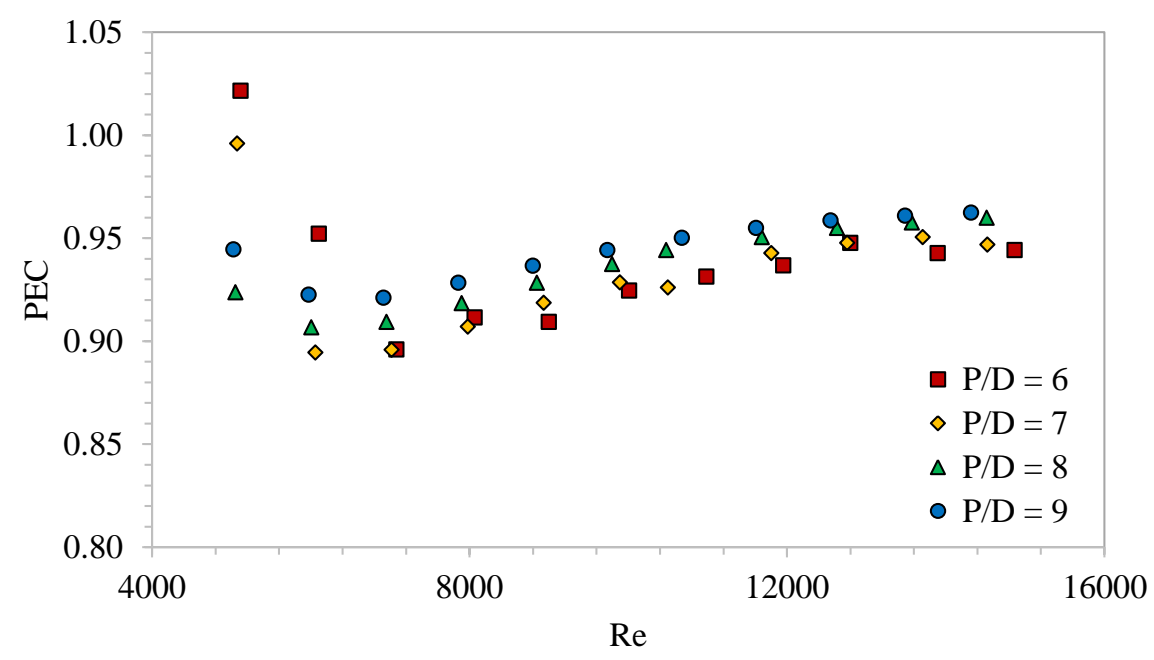

Figure7. PEC variation with Reynolds number for varying TRs

Velocity contours at the outlet of the tube for varying TR are demonstrated in Figure 8. As clearly seen, the flow pattern is quite different relative to the plain tube case since the use of TT insert improves fluid mixing, interruption of the thermal boundary layer and rise of the fluid temperature along the tube. Increasing in the TR, which causes the maximum velocity of fluid in the tube to increase as visually seen from Figure 8, accordingly improves the PEC due to changing flow pattern.

Temperature contours at the outlet of the tube for varying TR are demonstrated in Figure 9. As clearly seen, the temperature is high at the wall subjected to constant heat flux and then decreases gradually as moving to the central region of the pipe. The use of TT insert improves fluid mixing and thus the convection heat transfer coefficient which causes to transfer much heat from the wall. Increasing the TR lowers the wall temperature as visually seen from Figure 9, accordingly improves the PEC due to increasing temperature gradient between the wall and the pipe center. 


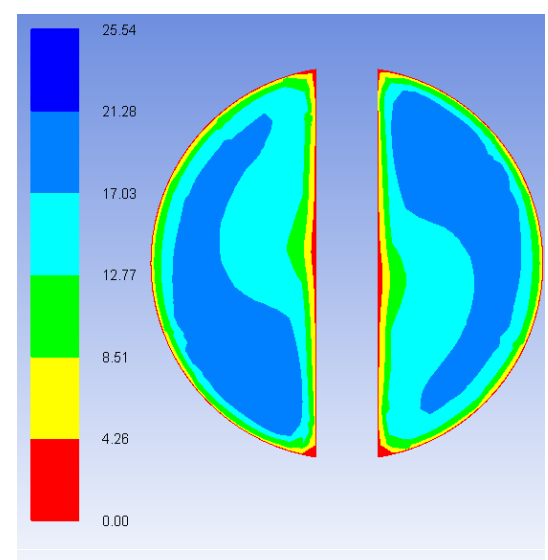

(a)

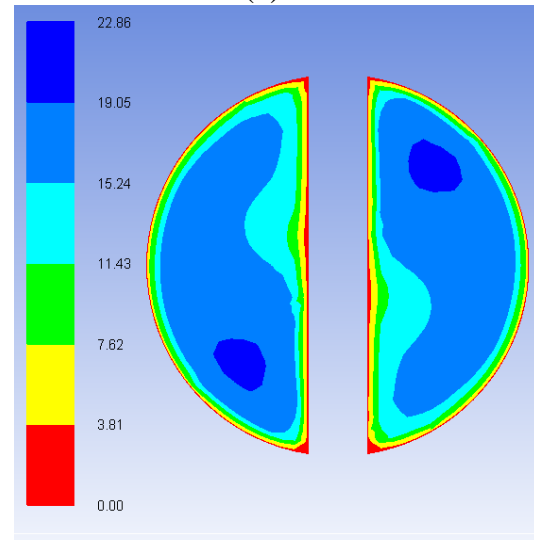

(c)

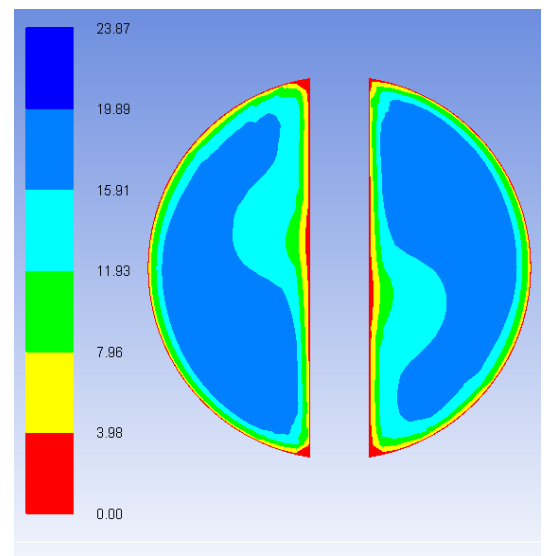

(b)

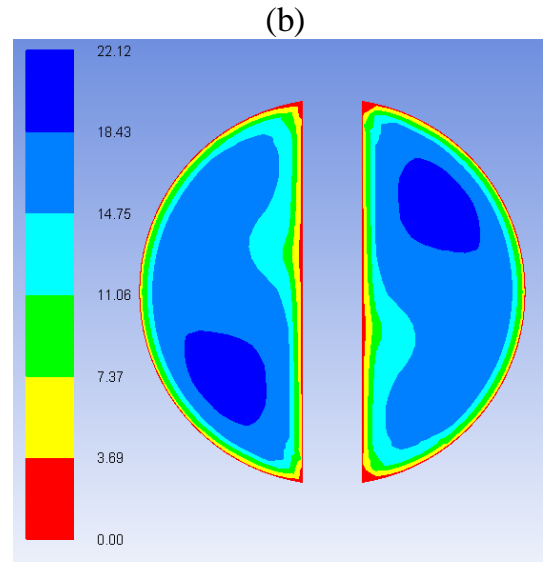

(d)

Figure 8. Velocity contours for varying $\mathrm{TR}$. (a) $\mathrm{TR}=6$, (b) $\mathrm{TR}=7$, (c) $\mathrm{TR}=8$, (d) $\mathrm{TR}=9$

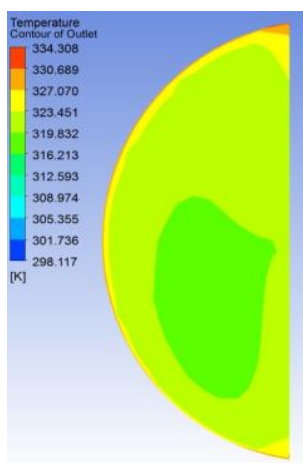

(a)

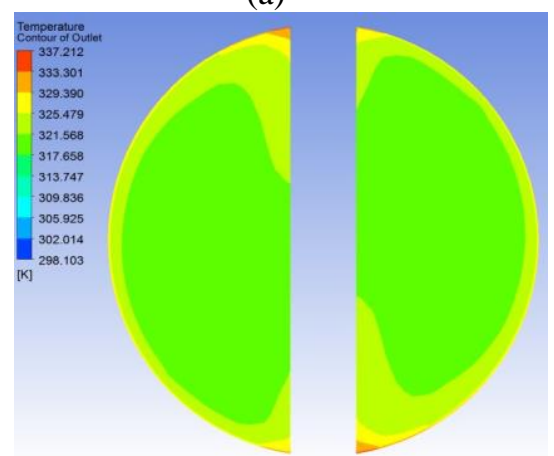

(c)
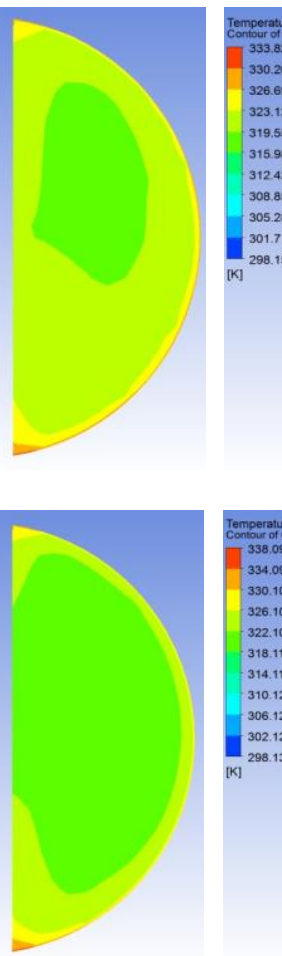

(b)
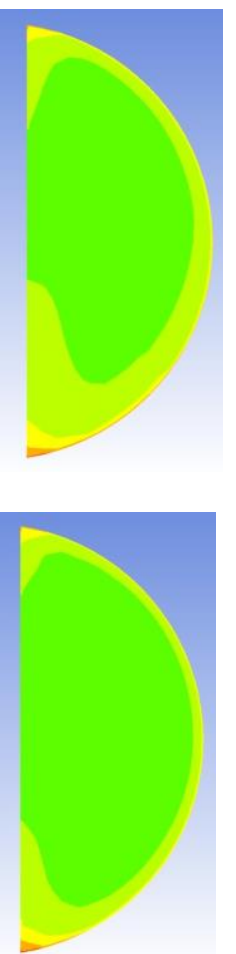

(d)

Figure 9. Temperature contours for varying TR. (a) $\mathrm{TR}=6$, (b) $\mathrm{TR}=7$, (c) $\mathrm{TR}=8$, (d) $\mathrm{TR}=9$ 


\section{Conclusions and Suggestions}

This study presents the thermo-hydraulic performance of a twisted tape inserted plain tube based on different twist ratios. A numerical model has been developed in Ansys Fluent for a tube geometry widely used in refrigeration applications. The twist ratio from 6 to 9 has been studied for the Reynolds number range of 5,025-14,871 using air as a working fluid. The findings of the study which reveal how efficiently this insert to be utilized for enhancing the heat transfer against pressure drop are as follows:

- While the use of twisted tape insert enhances the heat transfer at least $28 \%$ as compared to the plain tube case, it increases the friction factor at least $156 \%$ under the same operating conditions.

- Increasing the twist ratio is shown to be an ineffective parameter to increase Nusselt number.

- The use of twisted tape insert results in higher PEC values at low Reynolds number, i.e. the corresponding velocity of air at $5 \mathrm{~m} / \mathrm{s}$.

- Lowering the twist ratio has a negative impact on the PEC at increasing Reynolds numbers.

\section{Nomenclature}

$\begin{array}{ll}A_{s} & \text { surface area, } \mathrm{m}^{2} \\ c_{p} & \left.\text { fluid specific heat, } \mathrm{J} / \mathrm{kg} \cdot{ }^{\circ} \mathrm{C}\right) \\ D & \text { diameter of tube, } \mathrm{m} \\ D_{h} & \text { hydraulic diameter, } \mathrm{m} \\ f & \text { Darcy's friction factor } \\ f_{a} & \text { friction factor for twisted tape } \\ f_{o} & \text { friction factor for plain tube } \\ h & \text { heat transfer coefficient, } \mathrm{W} / \mathrm{m}^{2} \cdot \mathrm{K} \\ k & \text { fluid thermal conductivity, } \mathrm{W} / \mathrm{m} \cdot \mathrm{K} \\ L & \text { length of tube, } \mathrm{m} \\ \dot{m} & \text { mass flow rate of fluid, } \mathrm{kg} / \mathrm{s} \\ \mathrm{Nu} & \text { Nusselt number } \\ \mathrm{Nu} & \text { Nusselt number for twisted tape } \\ N u_{o} & \text { Nusselt number for plain tube } \\ \mathrm{P} & \text { pitch, } \mathrm{m} \\ \mathrm{Pr} & \text { Prandtl number } \\ \Delta P & \text { pressure drop, Pa } \\ \mathrm{Re} & \text { Reynolds number } \\ T_{b} & \text { bulk temperature, } \mathrm{K} \\ T_{i} & \text { inlet temperature, } \mathrm{K} \\ T_{o} & \text { outside temperature, } \mathrm{K} \\ T_{w} & \text { wall temperature, } \mathrm{K} \\ U_{m} & \text { mean velocity, } \mathrm{m} / \mathrm{s} \\ & \end{array}$

$\begin{array}{ll}\text { Abbreviations } & \\ \text { PEC } & \text { performance evaluation criteria } \\ \text { TR } & \text { twist ratio } \\ \text { TT } & \text { twisted tape } \\ \text { WC } & \text { wire coil }\end{array}$

\section{References}

[1] Mwesigye A., Y1lmaz İ.H., Meyer J.P. 2018. Numerical analysis of the thermal and thermodynamic performance of a parabolic trough solar collector using SWCNTs-Therminol ${ }^{\circ}$ VP-1 nanofluid, Renewable Energy, 119: 844-862. 
[2] Y1lmaz İ.H., Mwesigye A. 2018. Modeling, simulation and performance analysis of parabolic trough solar collectors: A comprehensive review, Applied Energy, 225: 135-174.

[3] Yılmaz İ.H., Mwesigye A., Göksu T.T. 2018. Enhancement of the thermal performance of a parabolic trough solar collector using wire coil inserts, SolarTR 2018, Solar Conference \& Exhibition, pp143-154, 29-30 November, Istanbul.

[4] Naphon P. 2006. Heat transfer and pressure drop in the horizontal double pipes with and without twisted tape insert, International Communications in Heat and Mass Transfer, 33: 166-175.

[5] Jaisankar S., Radhakrishnan T., Sheeba K. 2009. Experimental studies on heat transfer and friction factor characteristics of forced circulation solar water heater system fitted with helical twisted tapes, Solar Energy, 83: 1943-1952.

[6] Man C., Lv X., Hu J., Sun P., Tang Y. 2017. Experimental study on effect of heat transfer enhancement for single-phase forced convective flow with twisted tape inserts, International Journal of Heat and Mass Transfer, 106: 877-883.

[7] Eiamsa-Ard S., Promvonge P. 2010. Performance assessment in a heat exchanger tube with alternate clockwise and counter-clockwise twisted-tape inserts, International Journal of Heat and Mass Transfer, 53: 1364-1372.

[8] He Y., Liu L., Li P., Ma L. 2018. Experimental study on heat transfer enhancement characteristics of tube with cross hollow twisted tape inserts, Applied Thermal Engineering, 131: 743-749.

[9] Bharadwaj P., Khondge A., Date A. 2009. Heat transfer and pressure drop in a spirally grooved tube with twisted tape insert, International Journal of Heat and Mass Transfer, 52: 1938-1944.

[10] Hong Y., Du J., Wang S. 2017. Experimental heat transfer and flow characteristics in a spiral grooved tube with overlapped large/small twin twisted tapes, International Journal of Heat and Mass Transfer, 106: 1178-1190.

[11] Kanizawa F.T., Mogaji T.S., Ribatski G. 2014. Evaluation of the heat transfer enhancement and pressure drop penalty during flow boiling inside tubes containing twisted tape insert, Applied Thermal Engineering, 70: 328-340.

[12] Murugesan P., Mayilsamy K., Suresh S., Srinivasan P. 2011. Heat transfer and pressure drop characteristics in a circular tube fitted with and without V-cut twisted tape insert, International Communications in Heat and Mass Transfer, 38: 329-334.

[13] Wang L., Sunden B. 2002. Performance comparison of some tube inserts, International Communications in Heat and Mass Transfer, 29: 45-56.

[14] Eiamsa-Ard S., Nivesrangsan P., Chokphoemphun S., Promvonge P. 2010. Influence of combined non-uniform wire coil and twisted tape inserts on thermal performance characteristics, International Communications in Heat and Mass Transfer, 37: 850-856.

[15] Eiamsa-Ard S., Thianpong C., Eiamsa-Ard P. 2010. Turbulent heat transfer enhancement by counter/co-swirling flow in a tube fitted with twin twisted tapes, Experimental Thermal and Fluid Science, 34: 53-62.

[16] Bhuiya M., Sayem A., Islam M., Chowdhury M., Shahabuddin M. 2014. Performance assessment in a heat exchanger tube fitted with double counter twisted tape inserts, International Communications in Heat and Mass Transfer, 50: 25-33.

[17] Bhuiya M., Chowdhury M., Shahabuddin M., Saha M., Memon L. 2013. Thermal characteristics in a heat exchanger tube fitted with triple twisted tape inserts, International Communications in Heat and Mass Transfer, 48: 124-132.

[18] Man C., Yao J., Wang C. 2016. The experimental study on the heat transfer and friction factor characteristics in tube with a new kind of twisted tape insert, International Communications in Heat and Mass Transfer, 75: 124-129.

[19] Yılmaz İ.H., Saka K., Kaynakli O. 2016. A thermodynamic evaluation on high pressure condenser of double effect absorption refrigeration system, Energy, 113: 1031-1041.

[20] Yılmaz İ.H., Saka K., Kaşka Ö., Kaynaklı Ö. 2019. Performance assessment and solution procedure for series flow double effect absorption refrigeration systems under critical operating constraints, Arabian Journal for Science and Engineering (Accepted). 